\title{
W co wierzy \\ ochrzczony niewierzący, gdy zawiera małżeństwo?
}

\section{Wprowadzenie}

Problem ważności sakramentalności małżeństwa w opcji teorii o nierozdzielności kontraktu i sakramentu jest we współczesnej doktrynie żywo dyskutowany ze względu na zsekularyzowany kontekst, w którym bytuje współczesny wierny. Dyskusja ta nabiera szczególnego znaczenia w odniesieniu do osób ochrzczonych, które deklarują się jako niewierzące, a chcą zawrzeć małżeństwo według przepisów prawa kanonicznego. W tym kontekście rodzi się pytanie: czy zawarty przez nie związek będzie związkiem sakramentalnym? Tak zatytułował swój artykuł Rainer Alfs Kann ein getaufter, der nicht im Gott glaubt eine sakramentale Ehe schließen?'. Gerda Riedl zasygnalizowany problem nazwała „delikatnym zagadnieniem” (heikele Thema) ${ }^{2}$.

1 R. Alfs, Kann ein getaufter, der nicht im Gott glaubt eine sakramentale Ehe schließen?, w: Theologia et jus canonicum, Festgabe für Heribert Heinemann zum Vollendung seines 7o. Lebensjahr, Hrsg. H. J. F. Reinhard, Essen 1995, s. 397-413.

2 G. Riedl, Macht der Vertrag das Sacrament? Theologische Überlegungen zu einem heiklen Thema des kanonischen Eherehcts (c. 1055 CIC), „De Processibus Matrimonialibus" 13 (2006), s. 93. 
Wydaje się, iż próbując odpowiedzieć na określone w tytule wykładu pytanie, łatwiej będzie mi tego dokonać, jeśli sformułuję je negatywnie: kiedy małżeństwo ochrzczonego niewierzącego nie będzie już sakramentem? Uważam, że tym sposobem jednocześnie znajdę odpowiedź na pytanie postawione w tytule tego wykładu: w co powinien wierzyć niewierzący ochrzczony, zawierając małżeństwo?

Poszukując odpowiedzi, najpierw pragnę przywołać trafne spostrzeżenie Piera Antonia Bonneta, który zauważył, że w zakresie pojęcia „ochrzczony niewierzący” mieści się szeroki wachlarz postaw. Po pierwsze, poczynając od postawy charakterystycznej dla ochrzczonego ignoranta, a na postawie ochrzczonego niepraktykującego kończąc; po drugie, od postawy właściwej dla ochrzczonego, który utracił wiarę, ale we wnętrzu zachował religijność, po postawę ochrzczonego, który totalnie utracił wiarę; po trzecie, od postawy ochrzczonego, który nie akceptuje konceptu małżeństwa chrześcijańskiego w pewnych aspektach, po postawę ochrzczonego totalnie kontestującego sakramentalność małżeństwa³. Wielorakość postaw, o których mowa, wziął również pod uwagę prawodawca kościelny, co znalazło odzwierciedlenie w niektórych regulacjach materialnego prawa małżeńskiego. W zapisach normatywnych występują bowiem na przykład takie kategorie terminologiczne, jak: „, notoryczne porzucenie wiary katolickiej" (kan. 1071 § 1, nr 4 KPK ${ }^{4}$ ) czy też przed wprowadzeniem

3 Por. P. A. Bonnet, L'errore di diritto sulle proprietà essenziali e sulla sacramentalità, w: Error determinans voluntatem (can. 1099), a cura di P. A. Bonnet, C. Gullo, Città del Vaticano 1995, s. 48.

4 Codex Iuris Canonici auctoritate Joannis Pauli PP. II promulgatus, Typis Polyglottis Vaticanis 1983. Kodeks prawa kanonicznego. Przekład polski zatwierdzony przez Konferencję Episkopatu, Poznań 1984. 
motu proprio Omnium in mentem ${ }^{5}$ "odłączenie się od Kościoła katolickiego formalnym aktem" (kan. 1086, 1117, 1124 KPK).

Podejmując problematykę określoną w tytule wykładu, nie można abstrahować od pewnych wątków, które pojawiły się w okresie przed promulgacją kodeksu z 1983 roku.

\section{Okres przed promulgacją kodeksu z 1983 roku}

Poruszany w tym przedłożeniu problem nie jest nowy. Interesującą nas bowiem tematyką zajmowano się już podczas prac nad rewizją kodeksu z 1917 roku. W jednej z propozycji odniesiono się do kwestii ochrzczonych niewierzących, proponując wprowadzenie klauzuli typu: ,servatis iis quae ad validam sacramentorum receptionem requiruntur" (z zachowaniem tego, co jest wymagane co ważnego przyjęcia sakramentu) ${ }^{6}$. Odstąpiono jednak od tego zamiaru, ponieważ uznano, że jest to problem teologiczny, a nie prawny?

Oprócz tego Synodowi Biskupów z 1980 roku przedstawiono taką propozycję: „Quare inter baptizatos minima praesupposita requisita credendi cum Ecclesia nequit matrimonialis contractus validus consistere, quin sit eo ipso sacramentum" (Dlatego też między ochrzczonymi mającymi minimalną wiarę zgodną z wiarą Kościoła nie może być ważnego małżeństwa, które z samego faktu nie byłoby sakramentem) ${ }^{8}$.

5 Por. Benedictus PP. XVI, Litterae apostolicae motu proprio Omnium in mentem quaedam in Codice Iuris canonici immutantur, 26.10.2009, „Acta Apostolicae Sedis" 102 (2010), s. 8-10.

6 Coetus de Matrimonio. Sessio I: 21-25.02.1977, „Communicationes” 9 (1977), s. 122; R. Alfs, Kann ein getaufte..., dz. cyt., s. 407.

7 Por. R. Alfs, Kann ein getaufter..., dz. cyt., s. 407.

8 Relatio complectens animadversionum ab Em.mis atque Exc.mis patribus Commissionis ad Novissimum Schema Codicis Iuris Canonici exhibitum cum responsationibus a Segretaria et consultoribus datis, „Communicationes” 15 (1983), s. 221; R. Alfs, Kann ein getaufter..., dz. cyt., s. 407. 
Wreszcie podczas prac kodyfikacyjnych odrzucono wprowadzenie specjalnej przeszkody związanej z interesującą nas materią9.

Punktem wyjścia w naszych rozważaniach stanie się kwestia intencji zawarcia małżeństwa.

\section{Problem intencji zawarcia małżeństwa}

Jak wiadomo, w doktrynie dominuje teoria o nierozdzielności kontraktu i sakramentu. Krytycznie odnosząc się do tych założeń Riedl, zauważyła, iż w takiej sytuacji ochrzczony nie ma możliwości wyboru pomiędzy małżeństwem sakramentalnym a małżeństwem niesakramentalnym ${ }^{10}$. Apologeci tej teorii w swych argumentacjach głównie koncentrują uwagę na elemencie podmiotowym, wskazując, że prawo nie dysponuje takim narzędziem, aby można było precyzyjnie ustalić konieczny do ważności małżeństwa poziom wiary nupturienta. Poglądy te pozostają w ścisłym związku z rozważaną w doktrynie kwestią intencji generalnej koniecznej do zawarcia małżeństwa sakramentalnego. Mianowicie, kanoniści poszukując odpowiedzi na pytanie: czy do zawarcia takiego małżeństwa konieczna jest intencja sakramentalna, świadomi tego, iż niektórzy ochrzczeni zawierali związki małżeńskie jako niewierzący, nawiązywali do tradycyjnej tezy, że wystarczy intencja „czynienia tego, co czyni Kościół”. Pragnę przypomnieć, że zasada ta nie została sformułowana w czasach współczesnych, lecz w średniowieczu. Otóż w bulli Exultate Deo z 22 listopada 1439 roku Soboru Florenckiego stwierdzono m.in. „Wszystkie sakramenty dokonują się [...] przy udziale osoby szafarza przekazującego sakrament z intencją czynienia tego, co czyni Kościół”" Powtórzono

9 Por. P. Amenta, Matrimonio tra battezzati e disciplina ecclesiale: quale il rilievo della fede personale dei nubendi?, „Ephemerides Iuris Canonici” 53 (2013), s. 51.

10 Por. G. Riedl, Macht der Vertrag das Sacrament?..., dz. cyt., s. 97.

11 Sobór Florencki, Bulla unii z Ormianami, 22.11.1439, w: Dokumenty soborów powszechnych, oprac. A. Baron, H. Pietras, t. 3, Kraków 2003, s. 507. 
ją również na odbytej 3 marca 1547 roku Sesji 7 Soboru Trydenckiego $^{12}$. Co więcej, ten minimalny wymóg uwydatnia także współczesna doktryna. Czytając opracowania poświęcone tej tematyce, trzeba jednak zwrócić uwagę, że tylko na pozór mogłoby się wydawać, iż w kwestii znaczenia tego zwrotu występuje jednomyślność poglądów. Tak nie jest. W kilku publikacjach wskazuje się na szerokie spektrum opinii w tej kwestii (Sabbarese, Glinkowski) ${ }^{13}$. W wykładzie tym pragnę przytoczyć wyniki badań przeprowadzone przez Massima Mingardiego. W swej monografii L'esclusione della dignità sacramentale del consenso matrimoniale nella dottrina e nella giurisprudenza recenti ukazał on różne poglądy kanonistów w tej materii. I tak w jednym nurcie utrzymuje się, że konieczna jest intencja sakramentalna (Instrumentum laboris Synodu z 1980 roku, wyrok c. Pinto z 28 czerwca 1971 roku); inni autorzy uważają, że intencja ta powinna odnosić się bezpośrednio do małżeństwa (García Faílde, Maritz, Vanier, Finn, Kasper, Alfs, Mattia); jeszcze inni twierdzą, że nie można kontestować doktryny Kościoła (Gherro); wreszcie są i tacy uczeni, którzy nie określili dokładnie znaczenia tego doktrynalnego zwrotu (Baudot). Na drugim natomiast skrajnym biegunie spotykamy się poglądami, że wystarczy wola ochrzczonych zawarcia związku małżeńskiego, gdyż taka intencja implicite zakłada wolę „czynienia tego, co czyni Kościół” (Burke, Bersini, Navarrete, Grocholewski) ${ }^{14}$.

12 Zob. Sobór Trydencki, Dekret o sakramentach, 3.03.1547, Sesja 7, I/B, 11, w: Dokumenty soborów powszechnych, oprac. A. Baron, H. Pietras, t. 4, Kraków 2005, s. 359; Z. Grocholewski, L'errore circa l'unità, l'indissolublità e la sacramentalità del matrimonio, w: Diritto matrimoniale canonico, a cura di P. A. Bonnet, C. Gullo, t. 2, Città del Vaticano 2002, s. 243-244.

13 Por. L. Sabbarese, Fede, intenzionee dignità sacramentale nel matrimonio tra batezzati, „Periodica” 96 (2006), s. 284-286; B. Glinkowski, Symulacja catkowita zgody małżeńskiej w orzecznictwie Roty Rzymskiej (1965-1995), Poznań 2004, s. 106-108.

14 Por. M. Mingardi, L'esclusione della dignità sacramentale del consenso matrimoniale nella dottrina e nella giurisprudenza recenti, Roma 1997, s. 193-198. 
Pragnę zauważyć, iż w sytuacji, gdy mamy do czynienia z tradycyjnym założeniem doktrynalnym i zarazem w kanonistyce istnieją poważne problemy z jednoznacznym określeniem jego znaczenia, to w tej sytuacji bardzo trudno odpowiedzieć na pytanie: kiedy ta granica intencji generalnej, a zarazem intencji minimalnej zostałaby przekroczona. Co więcej, w oparciu o taki stan doktrynalny niełatwo precyzyjnie określić, w co niewierzący ochrzczony powinien wierzyć, zawierając sakramentalny związek małżeński?15 Wspomniana trudność wynika również z faktu, że wiara nie jest fenomenem jurydycznym, ale metajurydycznym. Zatem z aspektu prawnego odniesienie do niej stwarza poważne trudności interpretacyjne ${ }^{16}$. Trudno jest więc określić jej minimalny poziom konieczny do ważnego zawarcia sakramentalnego związku. Dlatego też w kan. 1055 § 2 KPK tego nie uczyniono.

Uważam, że w takiej sytuacji trzeba szukać innego klucza metodologicznego do rozwiązania interesującego nas problemu. Wydaje się, iż w dalszej kolejności należałoby przyjrzeć się mechanizmom funkcjonowania takich wad zgody, jak: symulacja sakramentalnej godności małżeństwa (kan. 1101 § 2 KPK) oraz błąd co do sakramentalnej godności małżeństwa (kan. 1099 KPK). Rozważając ten problem, Mingardi spostrzegł, że do niedawna uwaga uczonych koncentrowała się na elemencie podmiotowym, jakim był poziom wiary nupturienta; obecnie natomiast punkt ciężkości uwagi przenoszony jest bardziej na przedmiot konsensu ${ }^{17}$.

\footnotetext{
15 Por. B. Glinkowski, Symulacja całkowita..., dz. cyt., s. 106.

16 Por. M. Gas Aixendri, Ė possibile un matrimono valido senza fede?, w: Ius et matrimonium, a cura di H. Franceschi, M. A. Ortiz, Roma 2015, s. 145.

17 Por. M. Mingardi, L'esclusione..., dz. cyt., s. 149; M. Gas Aixendri, È possibile..., dz. cyt., s. 157 .
} 


\section{Wykluczenie sakramentalnej godności małżeństwa (kan. 1101 \ 2 KPK)}

Opierając się na doktrynie o nierozdzielności kontraktu i sakramentu, kanoniści do niedawna utrzymywali, że wykluczenie sakramentalności małżeństwa jest możliwe jedynie w przypadku symulacji całkowitej. Mechanizm powstania tej wady zgody Benedykt Glinkowski oddał następującymi słowami: „Całkowicie symuluje ten, który tak bardzo chce wykluczenia sakramentu, że gdyby musiał go przyjąć, woli nie zawierać związku małżeńskiego"18. Paolo Moneta, odnosząc się do tej kwestii, opisał kazus wiążący się z poważnymi trudnościami interpretacyjnymi. Mianowicie, szło o sytuację, w której ochrzczony niewierzący zawarł małżeństwo w kościele jedynie za względu na opinię społeczną, a w sposób szczególny ze względu na naciski swoich krewnych. Analizując ten przypadek, włoski kanonista napisał, że tradycyjna doktryna i judykatura rozpatrywała go wyłącznie z aspektu symulacji całkowitej, ponieważ łączono wykluczenie sakramentalności małżeństwa z intencją przeciwną katolickiej koncepcji małżeństwa ${ }^{19}$.

Myśl doktrynalna w interesującej nas kwestii jednak ewoluuje. Dobitnym przykładem tego jest fakt, że obecnie w Rocie Rzymskiej wydano kilka wyroków z symulacji częściowej wiążącej się $\mathrm{z}$ wykluczeniem sakramentalności małżeństwa ${ }^{20}$. W tej optyce argumentuje się, że nupturient powinien być świadomy wykluczenia sakramentalnej godności małżeństwa ${ }^{21}$. Zdaniem Mignardego

18 B. Glinkowski, Symulacja całkowita..., dz. cyt., s. 102.

19 Por. P. Moneta, Simulazione totale, w: Diritto matrimoniale canonico, t. 2, dz. cyt, s. 256; M. A. Ortiz, Fede e consenso matrimoniale, w: Matrimonio e famiglia, a cura di H. Franceschi, Roma 2015, s. 132.

20 Por. B. Glinkowski, Symulacja całkowita..., dz. cyt., s. 108; M. Gas Aixendri, È possibile..., dz. cyt., s. 156; R. Alfs, Kann ein getaufter..., dz. cyt., s. 406; A. P. Tavani, Fede e consenso matrimoniale, Torino 2013, s. 137-147.

21 Por. M. Mingardi, L'esclusione..., dz. cyt., s. 227. 
w przypadku tej specyficznej formy wykluczenia nie wystarczy generalna wola niechcenia (non volere) sakramentalności małżeństwa, ale potrzebna jest kwalifikowana wola wykluczająca sakramentalną godność, przeważająca nad intencją zawarcia małżeństwa ${ }^{22}$.

Stąd też w sensie pozytywnym we współczesnej kanonistyce, biorąc pod uwagę zapis nr 68 Adhortacji apostolskiej Familiaris consortio, wskazuje się, że do ważnego zawarcia małżeństwa sakramentalnego wystarczająca jest intencja zawarcia małżeństwa naturalnego, ponieważ w małżeństwach ochrzczonych intencja ta przedmiotowo jest ukierunkowana na zawarcie małżeństwa sakramentalnego. Jak pisze Miguel A. Ortiz, wola taka implikuje postawę posłuszeństwa woli Bożej ${ }^{23}$. Prawda ta została uwydatniona w sposób szczególny w wyroku c. Stankiewicz z 29 kwietnia z 1982 roku. Redaktor tej sentencji podkreślił bowiem z całym naciskiem, że w przypadku małżeństwa ochrzczonych niewierzących istotna jest nie tyle wiara, ile konsens, a szczególnie jego przedmiot. Rozwijając tę myśl, dodał, że jeśli nupturienci nie mieliby intencji „czynienia tego, co czyni Kościół”, wówczas małżeństwo byłoby nieważne, ponieważ odrzuciliby istotę małżeństwa chrześcijańskiego ${ }^{24}$.

Z punktu widzenia interesującego nas zagadnienia problem jest bardzo złożony, ponieważ dla osoby ochrzczonej zupełnie niewierzącej problem sakramentalności małżeństwa nie jest wymogiem konkretnym. Poruszając tę kwestię, Zenon Grocholewski zauważył, że jakże mógłby wykluczyć sakramentalną godność ktoś, dla

22 Por. M. Mingardi, L'esclusione..., dz. cyt., s. 231; P. Pellegrino, L'esclusione della sacramentalità del matrimonio, w: Diritto matrimoniale canonico, t. 2, dz. cyt., s. 382 .

23 Por. M. A. Ortiz, Fede..., dz. cyt., s. 131 i 138.

24 Por. Dec. c. Stankiewicz z 29.04.1982, RRD 74 (1987), s. 245-254; L. Sabbarese, Fede, intenzione e dignità sacramentale..., dz. cyt., s. 277-278. 
kogo jest ona problemem nieistniejącym; dla kogo sakramentalność nie ma żadnego znaczenia egzystencjalnego ${ }^{25}$. Z tego powodu, w jego opinii, zezwala się na zawarcie małżeństw mieszanych, a także na zawarcie związków osób, które wystąpiły z Kościoła formalnym aktem, gdyż uważa się, że większość zawartych związków jest prawnie skutecznych. W takich małżeństwach bowiem pomimo tego, iż u nupturienta (nupturientów) istnieje wola przeciwna sakramentalności małżeństwa, to jednak nie jest ona prawnie skuteczna ${ }^{26}$. Piero Pellegrino uważa, że większość przypadków wykluczenia sakramentalności wiąże się z postawami indyferentyzmu religijnego lub obojętności religijnej wyrażającymi się w wyraźnej woli przeciwnej Kościołowi ${ }^{27}$. Włoski kanonista rozważył ten problem z punktu widzenia prawa substancjalnego. Pisał, że brak wiary może znaleźć przełożenie w intencji nupturienta. Pomimo tego, że sama wiara nie jest elementem istotnym sakramentu, to jednak jej brak może oddziaływać tak na wolę, że ta z kolei może się przekształcić w pozytywny akt woli przeciwny sakramentalności małżeństwa ${ }^{28}$.

A więc jeśli mówimy o wykluczeniu sakramentalności małżeństwa, to mamy na myśli intencję jej przeciwną, wyraźnie sprofilowaną. Niektórzy kanoniści wiążą ją z postawą wojowniczą (atteggiamento belligerante) względem Boga i procesu zbawczego. W takiej sytuacji bowiem przyczyną symulacji staje się radykalny brak wiary ${ }^{29}$.

25 Por. Z. Grocholewski, L'errore circa l'unità, l'indissolublità e la sacramentalità del matrimonio, dz. cyt., s. 19.

26 Por. M. Mingardi, L'esclusione..., dz. cyt., s. 233.

27 Por. P. Pellegrino, L'esclusione..., dz. cyt., s. 381.

28 Por. P. Pellegrino, L'esclusione..., dz. cyt., s. 385.

29 Por. M. Gas Aixendri, Ė possibile..., dz. cyt., s. 160. 


\section{Błąd co do sakramentalnej godności małżeństwa (kan. 1099 KPK)}

Rozpatrując wadę zgody, jaką jest błąd co do sakramentalnej godności małżeństwa (kan. 1099 KРК), trzeba być świadomym tego, że ochrzczony może również utracić swą wiarę bez jego winy; bycie wierzącym nie zależy przecież wyłącznie od jego woli. Według Mingardiego brak wiary może stać się pewną formą niezdolności; oczywiście w tym wypadku nie idzie o niezdolność konsensualną, o której mowa w kan. 1095 KPK, ale o niezdolność do zawarcia małżeństwa sakramentalnego ${ }^{30}$. Rozważając tę kwestię na nowo, trzeba powrócić do konceptu „czynienia tego, co czyni Kościół”. Jak pisze Bonnet, u nupturienta powinien istnieć przynajmniej ślad wiary, aby zawierane przez niego małżeństwo było ważne ${ }^{31}$. Stąd też mając na uwadze parametr określony w kan. 1099 KPK, zgodnie z którym skuteczność prawną posiada jedynie błąd determinujący wolę, w doktrynie mówi się o kategorii „error personam pervadens"; błąd, o takiej charakterystyce musi dotyczyć elementu istotnego przedmiotu konsensu; idzie bowiem o zdeterminowaną wolę zawarcia małżeństwa niesakramentalnego ${ }^{32}$. Doktryna wiąże tego typu błąd z totalnym brakiem wiary lub totalną utratą wiary ${ }^{33}$. Bonnet mówi o pragnieniu zawarcia małżeństwa rozerwalnego ${ }^{34}$. Rozważając ten problem, Luigi Sabbarese pisze o ateizmie systematycznym, w którym odrzuca się kategorycznie odniesienie do Boga. Argumentując, stwierdził, iż w takiej sytuacji

30 Por. M. Mingardi, L'esclusione..., dz. cyt., s. 185-186.

31 Por. P. A. Bonnet, L'errore..., dz. cyt., s. 50.

32 Por. M. Mingardi, L'esclusione..., dz. cyt., s. 151-152; C. Burke, La sacramentalità del matrimonio: riflessioni canoniche, w: Sacramentalità e validità del matrimonio nella giurisprudenza del Tribunale della Rota Romana, a cura di P. A. Bonnet, C. Gullo, Città del Vaticano 1995, s. 149.

33 Por. Z. Grocholewski, L'errore..., dz. cyt., s. 245.

34 Por. P. A. Bonnet, L'errore..., dz. cyt., s. 56. 
bardzo trudno mówić o właściwej intencji zawarcia małżeństwa w znaczeniu intencji implicite czynienia tego, co czyni Kościół 35. Pragnę zauważyć, że taki sposób rozumienia tłumaczy m.in. inne podejście prawodawcy kościelnego do apostatów, którzy zawierają małżeństwo ważnie, jeśli zamierzają zawrzeć związek trwały, przepełniony charakterem sakramentalnym ${ }^{36}$.

W tym kontekście trzeba również odnieść się do kwestii sakramentalności małżeństw akatolików ochrzczonych. Wiadome jest, że we wspólnotach eklezjalnych protestanckich wierni nie wierzą w sakramentalność małżeństwa; u nich nie ma zatem intencji sakramentalnej. Święty Tomasz z Akwinu rozważył ten problem z punktu widzenia błędu wiary występującego u heretyków niewierzących w sakramentalność małżeństwa (,error fidei, qui est in haereticis non credentibus hoc sacramentum"37). Uważał, że tego typu błąd nie generował nieważności małżeństwa, dopóki nie godził w jego istotę („,circa ea quae sunt matrimonia consequentia"38). Jak napisał Salvatore Berlingò, w tym wypadku wystarczają, jak to określit, „dispsositiones habituales implicite”, które nie deformują tego, co czyni Kościół. A zatem wystarczająca jest tu intencja zawarcia małżeństwa, tak jak to czynią chrześcijanie; wystarczy postrzeganie małżeństwa jako daru Boga ${ }^{39}$. Mając na uwadze szerokie spektrum osób wchodzących w obszar pojęcia „ochrzczony niewierzący” w przypadku małżeństw protestantów, małżeństwa nie byłyby związkami sakramentalnymi, jeśli

35 Por. L. Sabbarese, Fede..., dz. cyt., s. 299-300.

36 Por. L. Sabbarese, Fede..., dz. cyt., s. 300.

37 S. Thomas Aquinas, Summa Theologiae. Tertia Pars et Supplementum, cura et studio Sac. P. Caramello cum textu ex censione Leoniana, Roma 1970, q. 51, a. 2.

38 Por. P. Amenta, Matrimonio..., dz. cyt., s. 50-51.

39 Por. S. Berlingò, Il matrimonio dei battezzati non cattolici e l'esclusione della sacramentalità, w: Matrimonio e sacramento, Città del Vaticano 2004, s. 124-125 i 133 . 
nupturient (nupturienci) wyraźnie kontestowaliby sakramentalną godność związku małżeńskiego ${ }^{40}$.

\section{Problem małżeństw mieszanych}

W kontekście prowadzonych rozważań powstaje jeszcze jeden istotny problem wiążący się z zapisem kan. $1125 \mathrm{nr} 1 \mathrm{KPK}$, w którym prawodawca domaga się od strony katolickiej ochrony swej wiary. Oznacza to zatem, że zakłada, iż przed zawarciem związku taką wiarę on posiada. W myśl doktryny wymóg ten wynika z prawa Bożego, od którego nie można dyspensować. W sytuacji zatem gdyby katolik przewidywał, że w planowanym związku nie będzie w stanie chronić czy też nie będzie chronił swej wiary, powinien odstąpić od zawarcia związku+11. Zarówno wymagane prawem zezwolenie, jak i dyspensa nie mogą zostać wydane.

Pragnę jednak zwrócić uwagę, że w tym wypadku inaczej trzeba podejść do sytuacji, w której zezwolenie lub dyspensa nie zostałyby udzielone w odniesieniu do związku katolika z akatolikiem ochrzczonym (kan. 1124 KPK), inaczej natomiast do związku katolika z nieochrzczonym (kan. 1086 крк). Mianowicie, w pierwszej hipotezie, jeśli pomimo nieuzyskania zezwolenia, doszłoby do zawarcia związku, wówczas przeważałaby teoria o nierozdzielności kontraktu i sakramentu; zawarte małżeństwo byłoby związkiem sakramentalnym, ale niegodziwym. O nieważności zawartego małżeństwa sakramentalnego można by natomiast mówić jedynie wtedy, gdyby wystąpiła omawiana już forma symulacji częściowej co do sakramentalnej godności małżeństwa (kan. 1101 § 2 KPK) bądź błąd determinujący wolę (kan. 1099 KРK).

\footnotetext{
40 Por. P. A. Bonnet, L'errore..., dz. cyt., s. 48.

41 Por. U. Navarrete, Disparitas cultus (can. 1086 CIC), w: Diritto matrimoniale canonico, a cura di P. A. Bonnet, C. Gullo, t. 1, Città del Vaticano 2002, s. 535; G. Dzierżon, Ewolucja doktryny oraz dyscypliny dotyczq̨cych przeszkody „różności religii” w kanonicznym porzq̨dku prawnym, Warszawa 2008, s. 316.
} 
W drugiej hipotezie natomiast w wyniku niemożliwości wydania dyspensy (kan. 1086 § 2 KPK) z powodu tego, że wymóg określony w kan. 1125 nr 1 KPK pochodzi z prawa Bożego, zawarte małżeństwo byłoby nieważne. Z tego rozwiązania systemowego wynika wyraźnie, iż ustawodawca w przypadku małżeństwa w konfiguracji katolik-nieochrzczony żąda istnienia u katolika pewnego poziomu wiary. Pragnę zauważyć, że wymóg ten nie koresponduje z tymi, które zostały zaprezentowane wcześniej. W związku z tym należałoby zapytać o ratio legis zapisu kan. 1086 $\S 2$ K PK? Trudno znaleźć jednoznaczną odpowiedź na to pytanie. Wydaje się, że domaganie się wiary od katolika wynika z faktu, iż z reguły życie w tego typu związkach wiąże się z poważnymi trudnościami, m.in. z ochrzczeniem i katolickim wychowaniem mającego się narodzić z tego związku potomstwa ${ }^{42}$.

Omawiając interesujący nas problem, nie można pominąć jeszcze jednego faktu, jakim jest Dekret Komisji do Spraw Ewangelizacji Konferencji Episkopatu Japonii z 19 kwietnia 1992 roku.

\section{Dekret Komisji do Spraw Ewangelizacji Konferencji Episkopatu Japonii z 19 kwietnia 1992 roku}

Udzielenie odpowiedzi na postawione w tytule wykładu pytanie komplikuje jeszcze bardziej rozwiązanie przyjęte w Japonii. Mianowicie, Dekretem Komisji do Spraw Ewangelizacji Konferencji Episkopatu Japonii z 19 kwietnia 1992 roku została zaaprobowana specyficzna praktyka zawierania małżeństw w tym kraju ${ }^{43}$. Otóż w „państwie kwitnącej wiśni” ukształtował się osobliwy zwyczaj

42 Por. U. Navarrete, Disparitas cultus..., dz. cyt., s. 519-521.

43 Por. J. Carreras, La giurisdizione della Chiesa sulle relazioni familiari, w: La giurisdizione della Chiesa sul matrimonio e sulla famiglia, a cura di J. Carreras, Roma 1998, s. 48. Cytuję za Carreras: Catholic Bishops of Japan. Comitte on Evangelzation, 
polegający na tym, że wkrótce przed zawarciem małżeństwa wielu japońskich nieochrzczonych narzeczonych udawało się do katolickich parafii w celu uzyskania błogosławieństwa. Tę praktykę pastoralną w 1975 roku aprobowała Kongregacja Doktryny Wiary, zezwalając proboszczom na udzielanie błogosławieństwa. W 1992 roku Konferencja Episkopatu Japonii wskazanym aktem prawnym uregulowała ją, określając obrzęd zawarcia takiego związku oraz ustalając prawne wymogi zawarcia małżeństwa. Zgodnie z zawartymi w nim zapisami nupturienci, po pierwsze, powinni przejść przygotowanie przedmałżeńskie trwające od 3-6 miesięcy; po drugie, zobowiązano małżonków do rejestracji zawartego związku, postrzeganego jako związek religijny, w instytucji państwowej w celu uzyskania cywilnej skuteczności prawnej.

Co więcej, w tym wypadku wymóg uprzedni wiąże się z faktem, że nupturienci biorący udział w katolickim przygotowaniu do zawarcia małżeństwa, winni podzielać katolicką doktrynę o nierozerwalności małżeństwa oraz nieskuteczności decyzji co do rozwodu, gdy idzie o rozwiązanie małżeństwa ważnego ${ }^{44}$.

\section{Podsumowanie}

Z rozważań tego wykładu wynika, że nie można udzielić jednoznacznej odpowiedzi na postawione w tytule pytanie, jeśli punktem odniesienia stanie się element podmiotowy. Nie da się bowiem precyzyjnie określić poziomu wiary, który generowałby nieważność małżeństwa sakramentalnego. Z tej perspektywy ustalenie minimalnej intencji generalnej koniecznej do zawarcia małżeństwa sakramentalnego staje się wręcz niemożliwe. Jest tak

Concerning Church Wedding in Wich Both Bride and Groom Are Non Christanns 19.04.1992, „The Japan Missonary Bulletin” 46 (1992), s. 256-26o.

44 Por. J. Carreras, La giurisdizione..., dz. cyt., s. 48-49; J. Llobell, La jurisdicción de la Iglesia sobre los matrimonios no obligados a la forma canónica, „Ius Canonicum" 37 (1997), s. 62-63. 
dlatego, ponieważ z jednej strony prawo jako dziedzina wiedzy nie dysponuje odpowiednimi narzędziami pozwalającymi zweryfikować zaistniały stan faktyczny, z drugiej zaś wiara jako fenomen jest fenomenem metajurydyczynym.

Z przeprowadzonych analiz wynika, że taką odpowiedź można uzyskać, jeśli odniesiemy się do komponentu przedmiotowego, jakim jest przedmiot konsensu. Wykazano bowiem, że jeśli nupturient w swej niewierze nie godzi w przedmiot konsensu, to wówczas zawarty związek małżeński będzie związkiem sakramentalnym. Udzielając odpowiedzi na pytanie, w co powinien wierzyć ochrzczony niewierzący, zawierając małżeństwo w kanonicznym porządku prawnym, trzeba stwierdzić paradoksalnie, że powinien mieć on przede wszystkim świadomość przedmiotu zgody małżeńskiej, zgodną z wizją Kościoła katolickiego; taka wola bowiem implikuje spełnienie tradycyjnego doktrynalnego wymogu „czynienia tego, co czyni Kościół”. Prawda ta znalazła potwierdzenie w przytaczanym wyroku c. Stankiewicz z 29 kwietnia z 1982 roku. Co więcej, za taką tezą przemawia również rozwiązanie przyjęte w Dekrecie Komisji do Spraw Ewangelizacji Konferencji Episkopatu Japonii z 19 kwietnia 1992 roku. Jeśli natomiast przyjmuje postawę aktywną godzącą w przedmiot zgody, wówczas przekracza dozwolone granice.

W namyśle nad takimi wadami zgody, jak: wykluczenie sakramentalnej godności małżeństwa (kan. 1101 § 2 KPK) i błąd co do sakramentalnej godności małżeństwa (kan. 1099 KPK) wykazano, iż interesująca nas granica zostałaby przekroczona, jeśli - gdy idzie o pierwszy tytuł - wola nupturienta zostałaby tak sprofilowana, że byłaby ona wyraźnie przeciwna sakramentalności małżeństwa; w drugiej hipotezie natomiast miałoby to miejsce, gdy świadomość nupturienta przeciwna sakramentalnej godności małżeństwa byłaby poważnie zakorzeniona w intelekcie. Generalnie rzecz biorąc, idzie zatem o postawy wyraźnie przeciwne 
Kościołowi i jego doktrynie o małżeństwie. Mogą one wynikać z wojowniczego ateizmu bądź niektórych postaci indyferentyzmu religijnego. Jeśli one nie wystąpiłyby, wtedy zawarto by związek sakramentalny.

I jeszcze jedno. Trudny problem, w moim przekonaniu, na chwilę obecną praktycznie nie do rozwiązania, stanowi konieczność sygnalizowanego $\mathrm{w}$ wykładzie poziomu wiary w przypadku zawierania małżeństwa przez katolika z nieochrzczonym (kan. 1086 KPK). Pragnę bowiem zauważyć, że wprowadzenie tego wymogu jest niekoherentne $\mathrm{z}$ wymogami minimalnymi omawianymi przed chwilą. Wydaje się, że jedyną racją przemawiającą za takim ustaleniem jest specyfika związku w konfiguracji, określonej w kan. 1086 KPK, domagającego się w sposób szczególny ochrony wiary katolika.

\section{SUMMARY}

\section{What Does a Baptized Non-believer Believe in When Contracting a Marriage?}

In the presented study, the author's main focus of attention was seeking answers to the question included in the title: "What Does a Baptized Nonbeliever Believe in When Contracting a Marriage?" Trying to answer such a research question, he pointed out that the answer cannot be obtained through referring to the subject element. According to the author, from this perspective, it is impossible to precisely determine the level of faith that would invalidate sacramental marriage. This is because, on the one hand, law as a field of knowledge does not have adequate tools to verify the existing facts, and on the other hand, faith as a phenomenon is meta-juridical. 
The author expressed his view that the act of marital consent should become the point of reference. Analyzing the mechanisms of functioning of two defects of the consent - namely, exclusion of the sacramental dignity of marriage (can. $1101 \S 2 \mathrm{CL}$ ) and error concerning the sacramental dignity of marriage (can. $1099 \mathrm{CL}$ ) - he proved that a baptized nonbeliever should not contest the object of marital consent consistent with the vision of the Catholic Church since this will, in his conviction, implies the fulfilment of the traditional doctrinal requirement of "doing what the Church does."

Keywords: canonical marriage, faith, sacrament, marital consent, theory of indissolubility of the contract and the sacrament

\section{StresZCZENIE}

\section{W co wierzy ochrzczony niewierzący, gdy zawiera małżeństwo?}

W zaprezentowanym opracowaniu głównym przedmiotem uwagi autora stało się poszukiwanie odpowiedzi na pytanie ujęte w jego tytule: „W co wierzy ochrzczony niewierzący, gdy zawiera małżeństwo?” Próbując odpowiedzieć na tak postawione pytanie badawcze, wskazał on, że nie można jej uzyskać w wyniku odniesienia do elementu podmiotowego. Zdaniem autora z tej perspektywy nie da się bowiem precyzyjnie określić poziomu wiary, który generowałby nieważność małżeństwa sakramentalnego, gdyż $\mathrm{z}$ jednej strony prawo jako dziedzina wiedzy nie dysponuje odpowiednimi narzędziami pozwalającymi zweryfikować zaistniały stan faktyczny, z drugiej zaś wiara jako fenomen jest fenomenem metajurydyczynym.

Wyraził on pogląd, że tym punktem odniesienia powinien być przedmiot zgody małżeńskiej. Analizując mechanizmy funkcjonowania dwóch wad zgody, jakimi są: wykluczenie sakramentalnej godności małżeństwa (kan. 1101 § 2 KPK) i błąd co do sakramentalnej godności małżeństwa (kan. 
1099 КРК), wykazał, iż niewierzący ochrzczony nie powinien kontestować przedmiotu zgody małżeńskiej, zgodnego z wizją Kościoła katolickiego; taka wola bowiem, w jego przekonaniu, implikuje spełnienie tradycyjnego doktrynalnego wymogu „czynienia tego, co czyni Kościół”.

Słowa kluczowe: małżeństwo kanoniczne, wiara, sakrament, zgoda małżeństwa, teoria o nierozdzielności kontraktu i sakramentu

Ginter Dzierżon, W co wierzy ochrzczony niewierzący, gdy zawiera małżeństwo?, w: Warunki dopuszczalności do sakramentów, ze szczególnym uwzględnieniem sakramentu małżeństwa, red. Piotr Kroczek, Kraków 2017, s. 7-24 (Annales Canonici Monographiae, 7).

DOI: http://dx.doi.org/10.15633/9788374388153.02 